\title{
Caravaggio's Judith and Holofernes: a forensic approach
}

\author{
Gianmarco Troiano ${ }^{1,4^{*}}$ (D), Isabella Mercurio ${ }^{2}$, Nicola Nante ${ }^{1,4}$ and Mauro Bacci ${ }^{3}$
}

Keywords: Art, History, Forensic medicine

\section{Sir,}

Michelangelo Merisi was born in September 1571 in Caravaggio, near Milan and was always known by the name of his hometown. Caravaggio moved to Rome in the early 1590s. His paintings were characterized by their extreme realism and dramatic contrasts of light and shade. Several works were realized as religious works commissioned by important exponents of clergy (BBC, 2017).

In this group of works should be included the two paintings about Judith and Holofernes, adapted from the Book of Judith. The Book of Judith is one of the three books in the Septuagint, and later Bibles, named for a woman: Judith, Esther, and Ruth. There is also one story named for a woman, the Story of Susanna, found in an addition to the Book of Daniel. Of the four women - Esther, Ruth, Susanna, and Judith - Judith is by far the most autonomous, politically engaged, and spiritually accomplished (Kevin et al., 2010).

The Book of Judith is the story of a Jewish heroine living during the period of the Second Temple when the Jewish community had returned from the Babylonian captivity and reestablished temple worship in Jerusalem. The story is famous for Judith's pursuit and beheading of the King's general, Holofernes (Kevin et al., 2010).

In 1599 Caravaggio painted the first "Judith Beheading Holofernes" (Fig. 1), an impressive canvas that tells the Biblical story of Judith, who saved her people by seducing and beheading the Assyrian general Holofernes, which was a common theme in the 16th century (Carvaggio.org, 2017).

\footnotetext{
* Correspondence: gianmarco.troiano@student.unisi.it; gianmarco89@hotmail.it

${ }^{1}$ Post Graduate School of Public Health University of Siena, Siena, Italy ${ }^{4}$ Department of Molecular and Developmental Medicine, Area of Public Health, University of Siena, 2 Via A. Moro, 53100 Siena, Italy Full list of author information is available at the end of the article
}

On April 2014 in the attic of a country house, not far from Toulouse, was found a lost painting, (Fig. 2). Afterwards, Eric Turquin's expert team analyzed the picture: without any doubt, the work is authentic. It represents Judith and Holofernes, and is similar to the previous canvas of Caravaggio, exhibited at the National Gallery of Ancient Art of Rome (Palazzo Barberini).

In this picture, however, the woman, who eliminates the threat of an Assyrian invasion of the Holy Land by decapitating the enemy general, is dressed in black (and not white as in the already known picture) and has a disturbing frontal look. According to French experts, the newly discovered painting dates back to 1604-1605, while the one already known was made in 1599 (Il Secolo XIX, 2017).

A previous study about the medical aspects of these painting has been realized: Perciaccante et al. analyzed a specific anatomical feature - the arterial spurt of blood - and showed a modification in its pictorial representation between the end of the 16th century and beginning of the 17th century. They speculated that the change in trajectory of the arterial spurt of blood from rectilinear to parabolic can be linked to the acquisition of new scientific knowledge (Perciaccante et al., 2016).

We decided to integrate the information given by these authors through a medico-legal evaluation of the two paintings.

\section{Description of the weapons}

The ancient swords had a very wide blade, with two parallel wires, cut at their end with symmetrical sides, and used only to inflict cutting hits. This aspect was unchaged also in XII and XIII century. The hilt was very simple: straight or with a cross aspect, a heavy handle, with a discoid form. In XIV century the hilt became more sophisticated.

In the two paintings there are important differences in the used weapon: in that of 1599 , the used weapon could 


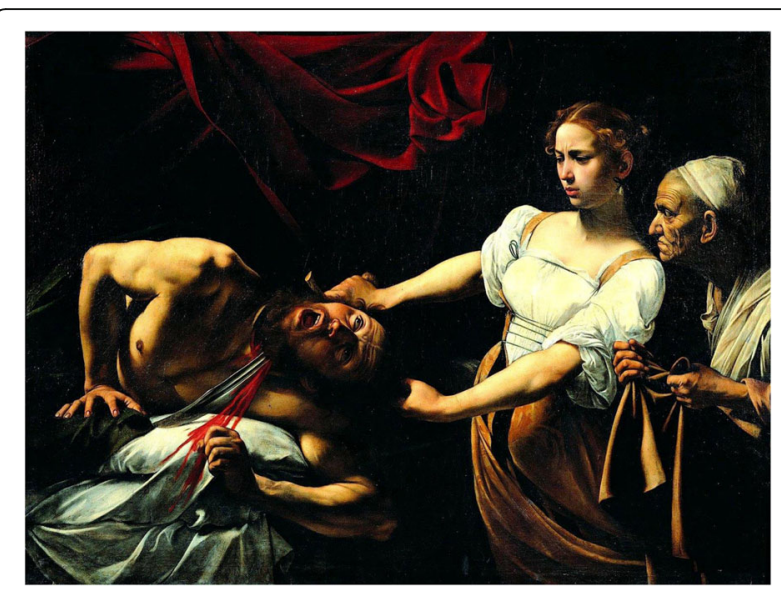

Fig. 1 "Judith Beheading Holofernes" (1599). (Available from https://commons.wikimedia.org/w/index.php?curid=10774618)

not be properly defined a "sword" because, according to the description made by Iacopo Gelli in his book (Pag. 294) (Gelli, 1968), it is more likely a hunting knife, although with a long blade.

In the second painting (the Tolouse painting) Judith uses another weapon: a big sword with a straight blade and a cross hilt, and a particular handle with a discoid form in its end. Typical of the XIII and following centuries (Pag. 300) (Gelli, 1968).

\section{Medico-legal evaluation}

In homicides where a cutter is used, the neck is the region that is most often affected (Mercurio et al., 2017). The wound that is generated is rapidly fatal if it affects the vascular-nervous bundle, particularly the carotid, which causes rapid spillage of blood with massive

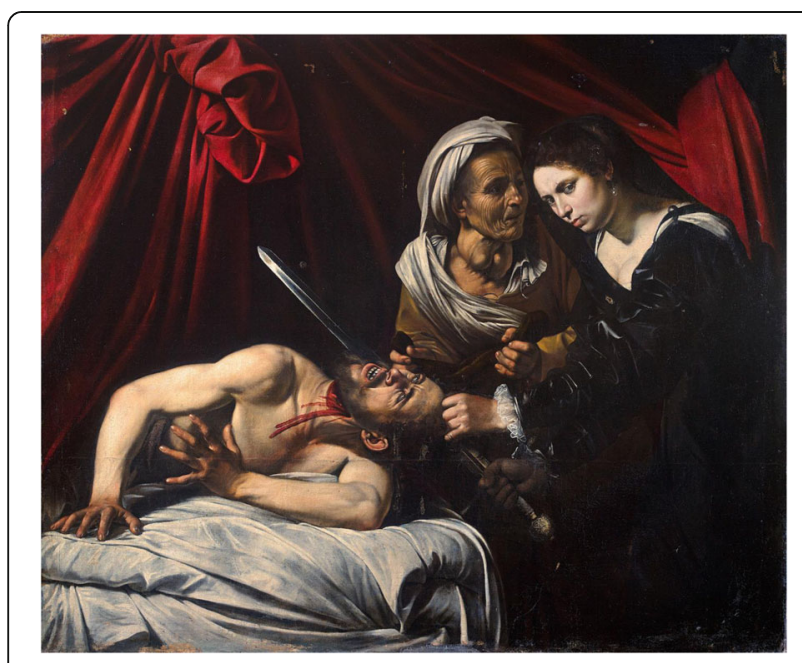

Fig. 2 The painting found in Toulouse. (Available from https://commons.wikimedia.org/w/index.php?curid=48144144) haemorrhage and shock. In other cases, when there is only a laryngeal or tracheal injury, death may occur by internal submersion for the entry of blood into the respiratory tract.

In the approach to cutting wounds, it is necessary to evaluate the anatomic location of the lesion, the surface extension, the depth, the regularity of the margins, and the tissue diastasis.

The margins of the cutting wounds are sharp, and the extent of the diastasis is correlated to the affected site, being maximum for the wounds arranged transversely in the neck for the presence of various muscles. If the knife meets a skin fold, margins may be discontinued.

The two paintings representing Judith and Holofernes painted by Caravaggio belong to two different periods of the author's life. There are many differences that can be observed between the two works. As already noted by Perciaccante et al. the direction of blood sketches is completely different. In the first painting, straight and downwards, in the second with parabolic and upward direction indicating that the theories concerning the motion of bullets were known by the author. The second picture therefore appears more truthful than the first, since it is a carotid lesion with hemorrhage that emerges rhythmically following the arterial pulse.

The different portrayed blood streams express the effect of time interfering with two heartbeats stuck on the canvas. It should be noted, however, that in carotid lesions blood streams also reach the distance of three meters for the driving force of the heart. In none of these cases Caravaggio describes this datum.

The margins cutting wounds are well described, since they are sharp and causing a wide spread of the tissues of the neck.

The dynamic of the event does not seem really correct. As it is evident from both canvases, the blood flows from the left carotid, that appears cut off at that instant. The knife, however, few instants after, is also chasing the right carotid, which, nevertheless, does not appear fluttering, although the neck is already cut to the right sternocleidomastoid region.

It is therefore likely that Caravaggio has witnessed to knives injuries, when the dynamics of arterial blood flow was still unknown (it was described by William Harvey in De Motu Cordis only in 1628).

The artist therefore described the arterial lesion on canvas and as if he had a direct knowledge of the dynamic of a vascular wound, but ignoring the details of the scarring wounds that will be known only later.

\section{Acknowledgements}

Not applicable.

Funding

Not applicable. 


\section{Availability of data and materials}

Data sharing not applicable to this article as no datasets were generated or analyzed during the current study.

\section{Author statements section}

This research did not receive any specific grant from funding agencies in the public, commercial, or not-for-profit sectors. The authors have not competing interests. This study not required any ethical approval because all data was provided and analyzed in anonymous form.

\section{Authors' contributions}

GT had the idea for the article, collaborated in performing the study, carried out the data analysis and collaborate in writing the article. IM had the idea for the article, collaborated in performing the study, carried out the data analysis and collaborate in writing the article. NN collaborated in writing the article and helped to conceptualize ideas. MB collaborated in writing the article and helped to conceptualize ideas. All authors read and approved the final manuscript.

\section{Ethics approval and consent to participate}

Not applicable.

\section{Consent for publication}

Not applicable.

\section{Competing interests}

The authors declare that they have no competing interests.

\section{Publisher's Note}

Springer Nature remains neutral with regard to jurisdictional claims in published maps and institutional affiliations.

\section{Author details}

${ }^{1}$ Post Graduate School of Public Health University of Siena, Siena, Italy. 2Department of Medical Sciences, Surgical and Neurosciences, Hospital Santa Maria alle Scotte, Siena, Italy. ${ }^{3}$ Section of Legal Medicine, Forensic Science and Sports Medicine, University of Perugia, Perugia, Italy. ${ }^{4}$ Department of Molecular and Developmental Medicine, Area of Public Health, University of Siena, 2 Via A. Moro, 53100 Siena, Italy.

Received: 8 September 2017 Accepted: 12 November 2017

Published online: 19 December 2017

\section{References}

BBC. Caravaggio (1571-610). [19/5/2017]; Available from: http://www.bbc.co.uk/ history/historic figures/caravaggio.shtml. Accessed 8 Aug 2017

Carvaggio.org. Judith Beheading Holofernes, 1599 by Caravaggio. [19/5/2017]; Available from: http://www.caravaggio.org/judith-beheading-holofernes.jsp

Gelli I (1968) Guida del Raccoglitore e Dell'amatore Di Armi Antiche. Hoepli, Milano

Kevin R, Brine EC, Lähnemann H (2010) The sword of Judith. Open Book Publisher, Cambridge

Mercurio I, Troiano G, Melai P, Zappulla M, Agostinelli V, Nante N, et al. (2017) "A 10 year post-mortem analysis of keratin matrix in Perugia (Ityaly): focus on cocaine involvement on several types of death". Aust J Forensic Sci 49(6): 711-719. doi:10.1080/00450618.2016.1264479

Perciaccante A, Charlier P, Coralli A, Bianucci R (2016) There will be blood'. Differences in the pictorial representation of the arterial spurt of blood in Caravaggio and followers. European journal of internal medicine 34:e46-ee7 Epub 2016/06/30

II Secolo XIX. Caravaggio dimenticato in una soffitta di Tolosa, gli esperti: è autentico. 2016 [19/5/2017]; Available from: http://www.ilsecoloxix.it/p/ cultura/2016/04/12/ASYkajKC-caravaggio_dimenticato_autentico.shtml 